\title{
EVALUATION OF THE ANTIMICROBIAL ACTIVITY OF IRON OXIDE NANOCATALYST DOPED WITH NANOPARTICLES ${ }^{1}$
}

\author{
AVALIAÇÃO DA ATIVIDADE ANTIMICROBIANA DE NANOCATALISADORES DE \\ ÓXIDO DE FERRO DOPADO COM NANOPARTÍCULAS
}

\author{
Pâmela Cristine Ladwig Muraro², Gabriela Pereira Chuy ${ }^{3}$, \\ Bruno Stefanello Vizzotto ${ }^{4}$, Sérgio Roberto Mortari ${ }^{5}$, William Leonardo da Silva ${ }^{6}$
}

\begin{abstract}
The synthesis of metallic nanocatalysts has been a new technological alternative found by researchers to corroborate in the Treatment of Water and Sewer because they have physical and chemical properties for the disinfection of water, analyzed through antimicrobial activity. Thus, this study aims to evaluate the antimicrobial activity of iron oxide nanocatalysts (undoped and doped with metallic nanoparticles). The synthesis of the iron oxide nanocatalysts was by the sodium borohydride oxy-reduction method and doping by impregnation method. Two methodologies were used to assess antimicrobial activity, the method by Disc-diffusion and Minimum Inhibitory Concentration (MIC) using the strains of Staphylococcus aureus (ATCC 25923) and Escherichia coli (ATCC 25922). The results showed that the majority of the nanocatalysts did not show antimicrobial activity, whereas the pure nanocatalyst in the proportion of 2:1 (w/w) showed biological activity up to the concentration of $1.25 \mathrm{mg} \cdot \mathrm{L}^{-1}$.
\end{abstract}

Keywords: Biotechnology, Minimal Inhibitory Concentration, Nanotechnology.

\section{RESUMO}

A sintese de nanocatalisadores metálicos vem sendo uma nova alternativa tecnológica encontrada pelos pesquisadores para corroborar no Tratamento de Água e Esgoto, pois os mesmos apresentam propriedades fisico-químicas para a desinfecção da água, analisados por meio de ensaios de atividade antimicrobiana. Com isso, esse estudo tem como objetivo a avaliação da atividade antimicrobiana de nanocatalisadores de óxido de ferro (não dopados e dopados com nanopartículas metálicas). A síntese dos nanocatalisadores de óxido de ferro foi pelo método de oxirredução por borohidreto de sódio e a dopagem pelo método de impregnação. Foram utilizadas duas metodologias para avaliação da atividade antimicrobiana, sendo o método por Discodifusão e Concentração Inibitória Mínima (CIM) usando as cepas da Staphylococcus aureus (ATCC 25923) e Escherichia coli (ATCC 25922). Os resultados mostram que a maioria dos nanocatalisadores não apresentaram atividade antimicrobiana, enquanto o nanocatalisador puro na proporção de 2:1 (m/m) apresentou atividade biológica até a concentração de $1,25 \mathrm{mg} \cdot \mathrm{L}^{-1}$.

Palavras-chave: Biotecnologia, Concentração Inibitória Mínima, Nanotecnologia.

\footnotetext{
${ }^{1}$ Master's work

${ }^{2} \mathrm{PhD}$ student of the Nanoscience Graduate Program - Universidade Franciscana. E-mail: pamelamuraro@ufn.edu.br

${ }^{3}$ Biomedicine course student - Universidade Franciscana. E-mail: gabichuy.97@gmail.com

${ }^{4}$ Biomedicine course professor - Molecular Biology Laboratory - Universidade Franciscana. E-mail: bvizzotto@ufn.edu.br

${ }^{5}$ Co-supervisor. Professor of the Nanoscience Graduate Program - Universidade Franciscana. E-mail: mortari@ufn.edu.br

${ }^{6}$ Supervisor. Professor of Nanoscience Graduate Program - Universidade Franciscana. E-mail: w.silva@ufn.edu.br
} 


\section{INTRODUCTION}

The growing trend of microbial infections, the rapid spread of the resistance of microorganisms to antimicrobials and the development of multidrug-resistant strains through mutations represent a major risk to public health on a global scale; will be used in biomedicine and health (AKBAR et al., 2020).

Nanocatalysts (NCs) have become a relevant topic for research in recent years due to their extensive applications in various fields, such as diagnosis, biomarkers, cell labeling, antimicrobial agents, drug delivery and cancer therapy (MOUSAVI et al., 2018). In addition, NCs are catalysts with a band size of about 10-1000 nm that can be synthesized by physical and / or chemical methods (MELO; PIMENTA, 2010). Various chemical and physical routes can be used for the synthesis of NCs, for example by sol-gel method (DOS SANTOS et al., 2014), oxy-reduction by chemical route (SUN et al., 2006) or green synthesis (CHANDRAN et al, 2006).

NCs with metallic oxide have been explored due to their antimicrobial activity against a variety of microorganisms that are known to cause common hospital-acquired infections (ABO-ZEID; WILLIAMS, 2019). In addition, they can be a very promising path for the development of new antimicrobial therapeutic alternatives, such as topical use for bacterial infections (RIOS et al., 2016). The antibacterial effects of metallic NCs are due to damage to cell membranes, production of reactive oxygen species (ROS), disturbances in homeostasis, genotoxicity and damage to proteins or enzymes (NISAR et al., 2019). In addition, microorganisms are not able to develop resistance to the production of ROS, since they attack the different sites and different biomolecules of the organism, resulting in their oxidation and cell death T (ABO-ZEID; WILLIAMS, 2019).

In this context, the present work aims to evaluate the antimicrobial activity to verify a possible biological applicability of metallic nanocatalysts, where the analysis was performed against the strains of Staphylococcus aureus ATCC 25923, Escherichia coli ATCC 25922 and Pseudomonas aeruginosa ATCC 27853 using the Disc-diffusion and Minimum Inhibitory Concentration (MIC), according to CLSI recommendations (2018).

\section{MATERIALS AND METHODS}

\section{SYNTHESIS OF IRON NANOPARTICLES}

For the synthesis of the iron oxide nanocatalyst (FeNPs), chemical precipitation methodology was used with sodium borohydride like reducing agent, according to the literature (SUN et al., 2006). Thus, $\mathrm{NaBH}_{4}\left(0.2\right.$ mol.L ${ }^{-1}$, Neon, $\left.99.9 \%\right)$ and $\mathrm{FeCl}_{3} \cdot 6 \mathrm{H}_{2} \mathrm{O}\left(0.05\right.$ mol.L $\mathrm{L}^{-1}$, Synth, $\left.99.9 \%\right)$ were mixed in a reactor with three mouths of the flask for 30 minutes with magnetic stirring $(250 \mathrm{rpm})$. After, iron 
nanoparticles generated were vacuum filtered and washed with deionized water and diluted ethanol (about 5\% v/v). Moreover, $\mathrm{pH}( \pm 7)$, concentrations reagents, stirring speed, reaction time and external temperature $\left(23 \pm 0.5^{\circ} \mathrm{C}\right)$ were kept constant, to avoid any influence of these on the composition and properties surface of the synthesized iron nanoparticles.

\section{SYNTHESIS OF SILVER NANOPARTICLES}

For the silver nanoparticles (AgNPs), the redox method was used, according to the literature (MELO Jr et al., 2012). Thus, $75 \mathrm{~mL}$ of a sodium borohydride solution $\left(2.0 \times 10^{-3} \mathrm{~mol} . \mathrm{L}^{-1}\right.$, Neon, $99.9 \%$ ) were added under an ice bath for 10 to $15 \mathrm{~min}$. Then, under magnetic stirring, $25 \mathrm{~mL}$ of a silver nitrate solution (1.0 x 10 $0^{-3} \mathrm{~mol}_{\mathrm{L}}^{-1}$, Sigma, $\left.99.9 \%\right)$ were added, with an addition rate of $1 \mathrm{drop} \mathrm{s}^{-1}$, forming the silver nanoparticles.

\section{DOPED NANOCATALYST}

For the doping of the iron oxide nanocatalyst, impregnation methodology (DA SILVA et al., 2016) was used with AgNPs and commercial titanium nanoparticles (TiNPs) using a concentration of $25 \% \mathrm{w} / \mathrm{w}$ of nanoparticles on the surface nanocatalyst. Thus, after magnetic stirring at room temperature for $90 \mathrm{~min}$, the sample was calcined under $450{ }^{\circ} \mathrm{C}$ (heating rate $10{ }^{\circ} \mathrm{C} \mathrm{min}{ }^{-1}$ ) for $4 \mathrm{~h}$. Then, granulometry was uniform with grinding and sieving (\#12), and the samples were labeled as AgNPs- $\mathrm{Fe}_{2} \mathrm{O}_{3}$ and TiNPs- $\mathrm{Fe}_{2} \mathrm{O}_{3}$, respectively.

\section{BACTERIAL STRAINS}

In order, to verify a possible biological activity of nanocatalysts, antimicrobial analysis was performed with the strains of Staphylococcus aureus ATCC 25923 and Escherichia coli ATCC 25922 provided by Molecular Biology Laboratory at Franciscan University (UFN).

Firstly, microorganisms were reactivated on Luria-Bertani broth $\left(\right.$ Merck $\left.^{\circledR}\right)$ for $18-24 \mathrm{~h}$ at $37 \pm$ $2{ }^{\circ} \mathrm{C}$. Then, the bacterial growth was sown on MacConkey agar (Merck ${ }^{\circledR}$ ) and Nutrient agar (SigmaAldrich $^{\circledR}$ ) and incubated at the same incubation conditions. For the preparation of bacterial inoculums, 3-4 colonies of each microorganism were transferred to microtubes containing $1 \mathrm{~mL}$ of sterile distilled water, cell density being adjusted to $0.1 \mathrm{OD}$ at $625 \mathrm{~nm}$, equivalent to the $0.5 \mathrm{McFarland}$ scale (1x10 ${ }^{8}$ CFU.mL $\left.L^{-1}\right)$, under UV spectrophotometer (Winex, UV 1100, USA). 
Disk-diffusion method was carried out to evaluate the antimicrobial activity of the nanocatalysts, according to CLSI recommendations (2018). The assay was executed in triplicate, where with the aid of a bacteriological loop, 2-3 bacterial colonies of the same morphology were collected, from the overnight culture, the same being resuspended in $5 \mathrm{~mL}$ of Mueller-Hinton broth (Sigma), in order to obtain a turbidity corresponding to $0.5 \mathrm{McFarland}$ scale. After homogenizing the inoculum in vortex, a sterile swab was inserted into the tube, which was compressed against the tube wall to remove excess liquid. The inoculation was carried out on the surface of Mueller-Hinton agar plates (Sigma-Aldrich), pressing the swab against the medium and dispensing the inoculum in the form of striations in three directions along the entire length of the culture plate, then left dry for 15 minutes. Sterile filter paper discs were placed in a sterile petri dish, where they received $20 \mu \mathrm{L}$ of nanocatalysts ( $5 \mathrm{mg} \cdot \mathrm{mL}^{-1}$ ) diluted in water, being subjected to 30 minutes of drying. These were then applied to the surface of the inoculated Mueller-Hinton agar, with the aid of sterile forceps to avoid contamination. All discs were gently pressed to ensure full contact with the agar surface. The plates were incubated for $18-24 \mathrm{~h}$ at $37 \pm 2{ }^{\circ} \mathrm{C}$ for subsequent measurement of the inhibition zones (in millimeters) and analysis of bacterial susceptibility.

\section{MINIMUM INHIBITORY CONCENTRATION (MIC)}

MIC determination of nanocatalysts was carried out by microdilution method in triplicate, according to CLSI recommendations (2018). Thus, were used 96-well polystyrene microplates (Figure 1) with nanocatalysts (undoped and doped) diluted in sterile distilled water at a concentration of 5 mg.mL ${ }^{-1}$. After, $100 \mu \mathrm{L}$ of Mueller Hinton broth (MH) were added to each of the 96-well plate and homogenized. Then, $100 \mu \mathrm{L}$ aliquot of the contents were transferred to adjacent columns, and successively until the end of the plate, performing a serial dilution of the nanocatalysts in the proportion $1: 2 \mathrm{v} / \mathrm{v}\left(5 \mathrm{mg} \cdot \mathrm{mL}^{-1}\right.$ to $\left.0.009 \mathrm{mg} \cdot \mathrm{mL}^{-1}\right)$. After, $10 \mu \mathrm{L}$ of the bacterial inoculums $\left(1 \times 10^{4} \mathrm{CFU} \cdot \mathrm{mL}^{-1}\right)$ were added to all wells. For the positive control, only MH broth and the bacterial inoculum were used (viability control), and only $\mathrm{MH}$ broth as a negative control (contamination control). Thus, microplates were incubated for $18-24$ hours at $37 \pm 2{ }^{\circ} \mathrm{C}$. After this incubation, $20 \mu \mathrm{L}$ of $5 \%(\mathrm{v} / \mathrm{v})$ triphenyltetrazolium chloride (CTT) were added to each well, and the plates were reincubated for an additional 2 hours. MIC reading was done visually, where the color changed from colorless to red indicated bacterial growth, with the MIC defined as the lowest concentration (in mg. $\mathrm{L}^{-1}$ ) of the nanocatalysts responsible for preventing bacterial growth. 
Figure 1 - Representation nanocatalysts distribution in the 96-well plate for MIC tests.

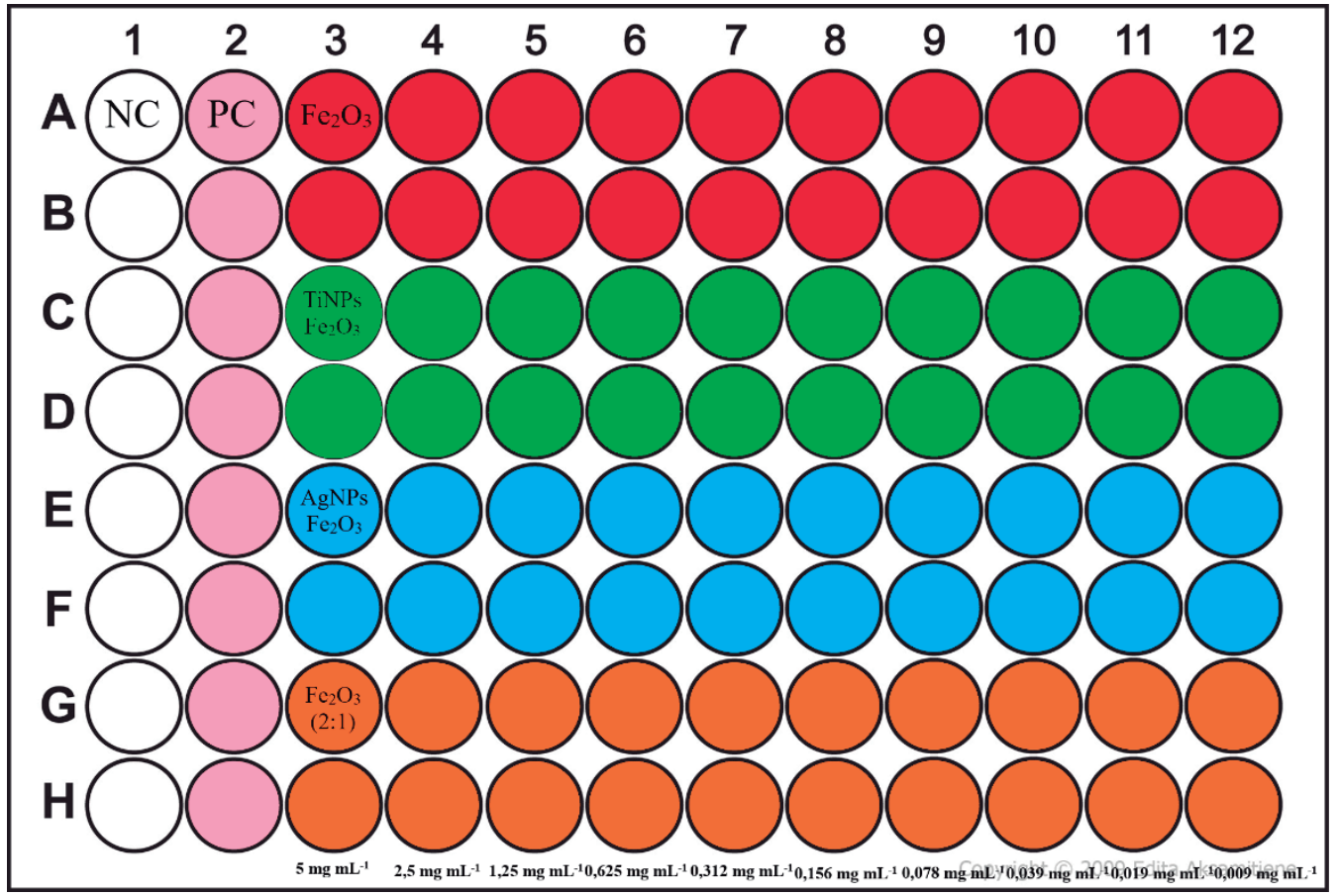

NC: Negative control. PC: Positive control. 3-12: Nanocatalysts concentrations ranging from 5mg.mL $\mathrm{mL}^{-1}$ to $0.009 \mathrm{mg}^{\mathrm{mL}} \mathrm{mL}^{-1}$. Source: Author.

\section{PHOTOBACTERICIDAL ACTIVITY}

To determine the photobactericidal activity, two MIC microplates (Figure 3) were exposed for each microorganism in the presence of the doped nanocatalyst, where one plate was subjected to incubation in the absence of light, and another plate remained exposed for 2 hours under visible light, according the literature (HWANG et al, 2020). Bacteria were put in contact with each compound for 4 hours at $37^{\circ} \mathrm{C}$ in the dark, and then the plates were irradiated with visible light for $60 \mathrm{~min}$. After irradiation, the plates were incubated overnight $37^{\circ} \mathrm{C}$ under aerobic conditions. The lowest concentration of each nanocatalysts that prevented bacterial growth was considered as the MIC of that compound. Three independent experiments were performed with each strain (SOLIMAN et.al., 2020).

\section{RESULTS AND DISCUSSION}

Antimicrobial activity results by disc-diffusion with nanocatalysts (undoped and doped with nanoparticles) are showed at Figure 2. It was observed that there was no inhibition of the growth of microorganisms in the plates, also there was no homogeneous distribution of the compounds on the disk, probably not allowing sufficient contact of these with the seeded plate, which prevented the use of the disc-diffusion assay in a satisfactory way to determine the antimicrobial activity. 
Figure 2 - Disc-diffusion results of the nanocatalysts with E. coli ATCC 25922.

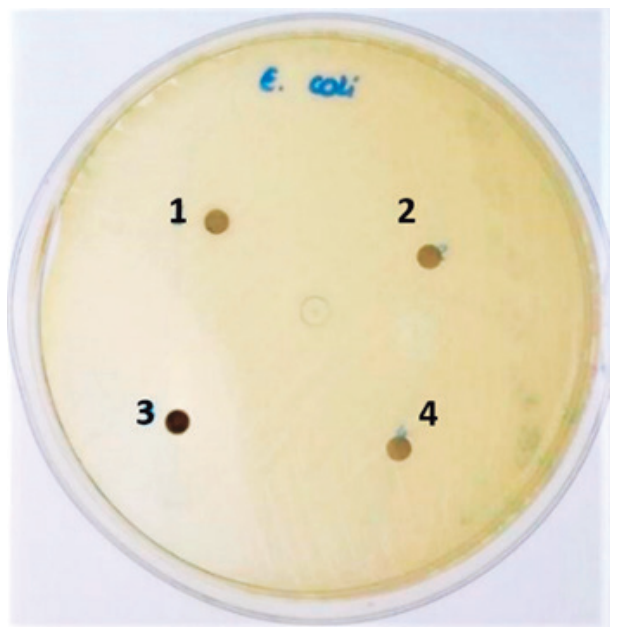

1. Iron oxide undoped with AgNPs 2. Iron oxide doped with AgNPs

3. Iron oxide undoped with TiNPs 4. Iron oxide doped with TiNPs

Source: Author.

MIC results by microdilution method for the strains tested are showed at Figure 3, where doped and undoped nanocatalysts were not efficient for two of the three microorganisms tested. However, by the observation of inhibition zones made by the diffusion disk and MIC, it can be noted that the E. coli bacteria showed greater sensitivity than the other microorganisms tested.

Figure 3 - MIC results of the nanocatalysts.
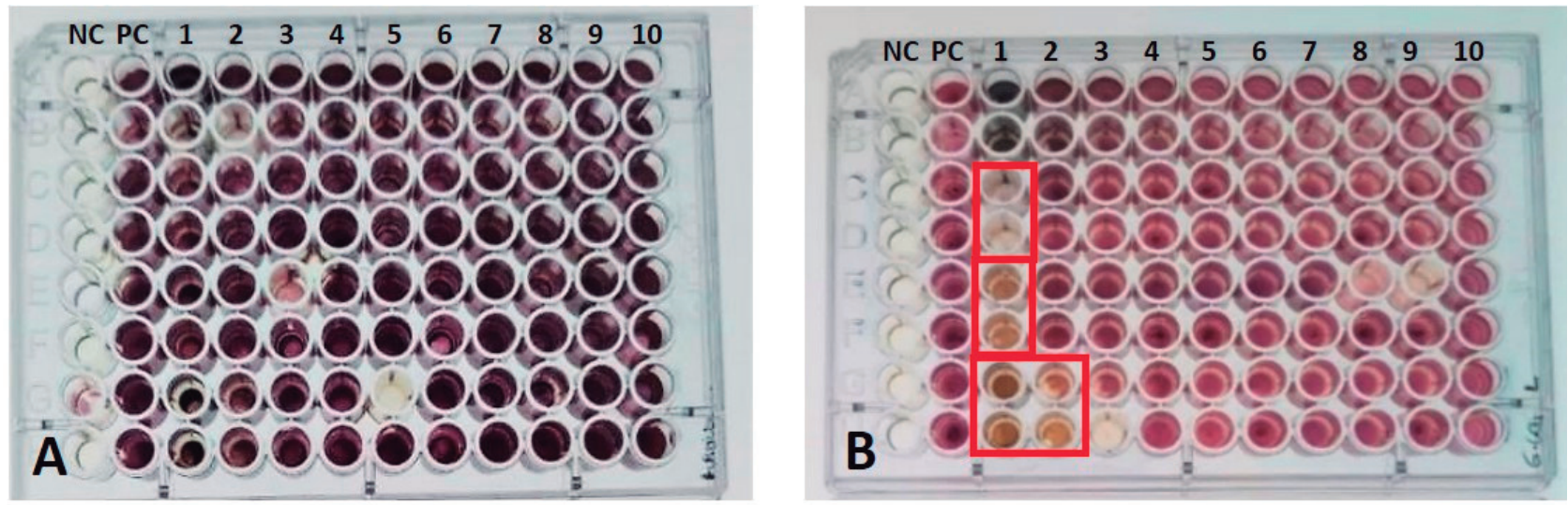

A: S. aureus ATCC 25923. B: E. coli ATCC 25922. NC: negative control.

PC: positive control. 1-10: Nanocatalysts concentrations ranging from $5 \mathrm{mg} \cdot \mathrm{mL}^{-1}$ to $0.009 \mathrm{mg} \cdot \mathrm{mL}^{-1}$.

Source: Author.

Oliveira (2017) evaluated the biological activity of the metallic nanoparticles, using disk diffusion method, and observed that the nanoparticles did not have an inhibitory effect against $E$. coli. Figure 4 shows the MIC results of the photobactericidal activity using visible irradiation. 
Figure 4 - MIC results with nanocatalysts under visible irradiation and

(A) S. aureus ATCC 25923. (B): E. coli ATCC 25922.
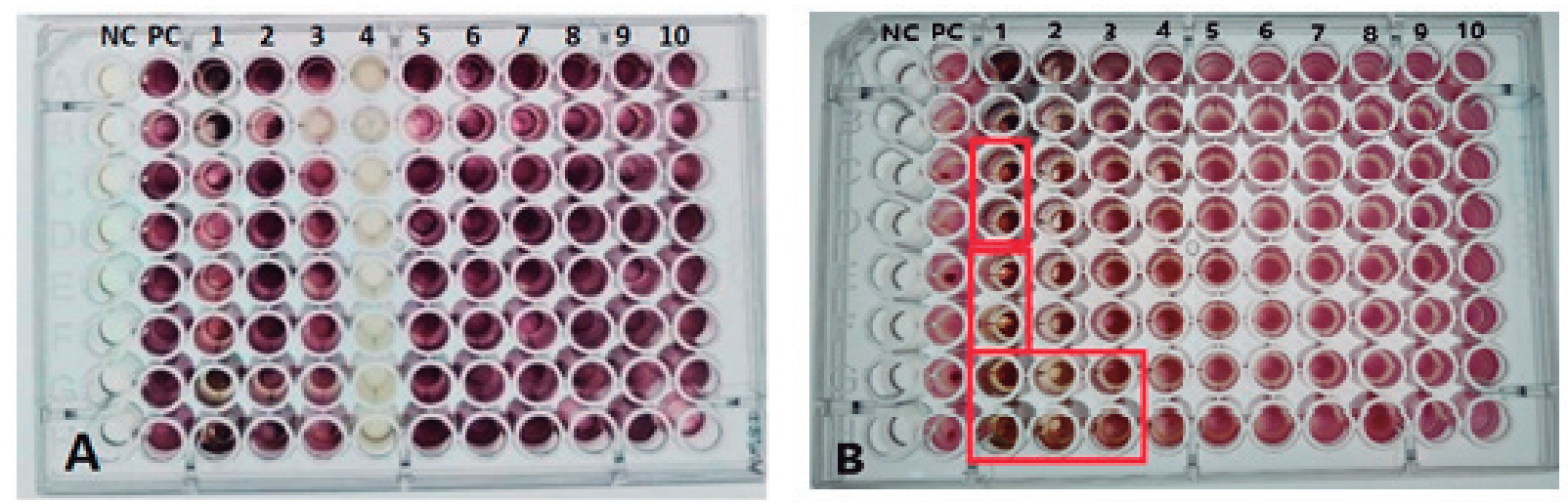

NC: negative control. PC: positive control. 1-10: Nanocatalysts concentrations ranging $5 \mathrm{mg} \cdot \mathrm{mL}^{-1}$ to $0.009 \mathrm{mg} \cdot \mathrm{mL}^{-1}$. Source: Author.

According to Figure 4, there was no antimicrobial activity of the nanocatalysts for S. aureus, both in the light and in the dark. Souza (2014) evaluated the antimicrobial activity of silver (AgNPs) and titanium (TiNPs) nanoparticles against the same bacteria, where NPs did not inactivate the growth of the isolate, which may be due to their low concentration, however, by increasing the concentration of NPs it is necessary to conduct a study on the toxicity of nanoparticles.

E. coli was more sensitive than the other microorganisms, since the MIC of the nanocatalysts for this microorganism was $2.5 \mathrm{mg} . \mathrm{L}^{-1}$ in the $\mathrm{Fe}_{2} \mathrm{O}_{3}$ sample $(2: 1 \mathrm{w} / \mathrm{w})$, indicating that the compound has a small activity against this microorganism. Shahverdi and collaborators (2007) compared antimicrobial activity of nanoparticles doped with polymethylmethacrylate (PMMA) with AgNPs against E. coli, where they found that nanofibers provided a higher rate of inhibition, since the bactericidal effect was influenced by the particle sizes, with the smaller particles the better effects.

Table 1 shows more visually the results obtained in the disk-diffusion, MIC and photobactericidal activity. Analyzing that $\mathrm{Fe}_{2} \mathrm{O}_{3}$ showed photobactericidal activity and the inhibition of E. coli bacteria to a concentration of $2.5 \mathrm{mg} \cdot \mathrm{L}^{-1}$.

Table 1 - Disc-diffusion, MIC values $\left(\mathrm{mg} \cdot \mathrm{mL}^{-1}\right)$ and photobactericidal activity $\left(\mathrm{mg} \cdot \mathrm{mL}^{-1}\right)$ of the compounds against microorganisms tested.

\begin{tabular}{ccccccc}
\hline & \multicolumn{3}{c}{ E. coli } & ATCC 25922 & \multicolumn{4}{c}{ S. aureus ATCC 25923} \\
\hline Compounds & DD & MIC & PA & DD & MIC & PA \\
\hline $\mathrm{Fe}_{2} \mathrm{O}_{3}$ & - & $>5$ & $>5$ & - & $>5$ & - \\
$\mathrm{AgNPs}_{\mathrm{Nge}} \mathrm{O}_{3}$ & - & $>5$ & $>5$ & - & $>5$ & - \\
$\mathrm{TiNPs}-\mathrm{Fe}_{2} \mathrm{O}_{3}$ & - & $>5$ & $>5$ & - & $>5$ & - \\
$\mathrm{Fe}_{2} \mathrm{O}_{3}(2: 1 \mathrm{w} / \mathrm{w})$ & - & 2,5 & 1,25 & - & $>5$ & - \\
\hline
\end{tabular}

DD: Disc-diffusion assay. MIC: Minimum Inhibitory Concentration.

PA: Photobactericidal Activity. The “_"signals indicate no inhibition zone observed.

Source: Author. 


\section{CONCLUSION}

The antimicrobial activity of the Disc-diffusion assay showed that the compounds did not show inhibitory effects with the tested bacteria, which may be due to the fact that the nanocatalyst was unable to spread on the plates and thus, therefore not coming into contact with the bacteria. For the MIC test, the compounds $\mathrm{Fe}_{2} \mathrm{O}_{3}$, TiNPs- $\mathrm{Fe}_{2} \mathrm{O}_{3}$ and $\mathrm{AgNPS}-\mathrm{Fe}_{2} \mathrm{O}_{3}$ did not show inhibitory effects for the evaluated bacteria, in all tested concentrations $\left(0.009 \mathrm{mg} . \mathrm{L}^{-1}\right.$ to $\left.5 \mathrm{mg} . \mathrm{L}^{-1}\right)$. With the $\mathrm{Fe}_{2} \mathrm{O}_{3}$ nanoparticle $(2: 1 \mathrm{w} / \mathrm{w})$ there was a small inhibitory effect of $2.5 \mathrm{mg} . \mathrm{L}^{-1}$ and on the photobactericidal activity of $1.25 \mathrm{mg} . \mathrm{L}^{-1}$. The low concentration of nanoparticles (AgNPs and TiNPs) may explain the lack of inhibition of the bacteria used. The comparison with other studies cannot be performed because there are no studies related to the $\mathrm{Fe}_{2} \mathrm{O}_{3}$ nanocatalyst. It is worth mentioning that more studies are needed to detect the best concentration of the dopant in the nanoparticle to have antimicrobial activity

\section{REFERENCE}

ABO-ZEID, Y.; WILLIAMS, G. R. The potential anti-infective applications of metal oxide nanoparticles: A systematic review. Wiley Interdisciplinary Reviews: Nanomedicine and Nanobiotechnology, v. 12, n. 2, p. 1592, 2020.

AKBAR, N.; PERTIWI, D.; NEVIATY, P. Z. N.; SUBHAN, B.; MADDUPPA, H. A pilot study on the population genetics of yellowfin tuna (Thunnus albacares) from two populations in the Moluccas Islands, Indonesia. Depik, v. 9, n. 1, p. 69-106, 2020.

BORCHERDING, J.; BALTRUSAITIS, J.; CHEN, H.; STEBOUNOVA, L.; WU, C.; RUBASINGHEGE, G.; MUDUNKOTUWA, I. A.; CARABALLO, J. C.; ZABNER, J.; GRASSIAN, V. H.; COMELLAS, A. P. Iron oxide nanoparticles induce pseudomonas aeruginosa growth, induce biofilm formation, and inhibit antimicrobial peptide function. Environmental Science: Nano, v. 1, p. 123-132, 2014.

CHANDRAN, P.; CHAUDHARY, M.; PASRICHA, R.; AHMAD, A.; SASTRY, M. Synthesis of gold nanotriangles and silver nanoparticles using Aloe vera plant extract. Biotechnology Progress, v. 22, p. 577-583, 2006.

CLINICAL AND LABORATORY STANDARDS INSTITUTE. Methods for dilution antimicrobial susceptibility tests for bacteria that grow aerobically. Approved standard -Seventh edition: M07-A09, v. 32, 2018. 
DA SILVA, W.L.; LASARIM, M. L.; DOS SANTOS, J. H.; SILVEIRA, F. Photocatalytic degradation of rhodamine B, paracetamol and diclofenac sodium by supported titania-based catalysts from petrochemical residue: effect of doping with magnesium. Water Science and Technology, v. 74, p. 2370-2383, 2016.

DOS SANTOS, A. M.; VASCONCELOS, J. S.; RANGEL, J. H. G.; LONGO, E.; OLIVEIRA, M. M. Synthesis of ceramic nanocatalyst based on $\mathrm{SnO}_{2}$ by microwave-assisted hydrothermal method applied to the babassu oil transesterification reaction. Ceramics, v. 60, p. 397-401, 2014.

HWANG, G. B.; HUANG, H.; WU, G.; SHIN, J.; KAFIZAS, A.; KARU, K.; MACROBERT, A. J. Photobactericidal activity activated by thiolated gold nanoclusters at low flux levels of white light. Nature communications, v. 11, n. 1, p. 1-10, 2020.

MELO, C.P.; PIMENTA, M. Nanoscience and nanotechnology. Strategic Partnerships, v. 9, p. 9-22, 2010.

MELO JR, M.A.; SANTOS, L.S.S., GONÇALVES, M.C., NOGUEIRA, A.F. Preparation of silver and gold nanoparticles: a simple method for the introduction of nanoscience in a teaching laboratory. New Chemistry, v. 35, p. 1872-1878, 2012.

MOUSAVI, M.; HABIBI-YANGJEH, A.; POURAN, S. R. Review on magnetically separable graphitic carbon nitride-based nanocomposites as promising visible-light-driven photocatalysts. Journal of Materials Science: Materials in Electronics, v. 29, n. 3, p. 1719-1747, 2018.

NISAR, F.; GUL, B.; KHAN, M. A.; HAMEED, A. Heteromorphic seeds of coastal halophytes Arthrocnemum macrostachyum and A. indicum display differential patterns of hydrogen peroxide accumulation, lipid peroxidation and antioxidant activities under increasing salinity. Plant Physiology and Biochemistry, v. 144, p. 58-63, 2019.

OLIANI, W.L. Study of the formation of nanogels and microgels of polypropylene modified by gamma radiation and incorporation of silver nanoparticles aiming at the biocidal action. 2013. $156 \mathrm{p}$. Thesis (Doctorate in Science) - Science Graduate Program, University of São Paulo, São Paulo, 2013.

OLIVEIRA, F.M. Synthesis of anisotropic gold nanoparticles and their evaluation as catalysts in the chemical reduction of p-nitrophenol. 2017. 70 p. Dissertation (Master of Science) - Graduate Program in Chemistry and Biotechnology, Federal University of Alagoas, Maceió, Alagoas, 2017. 
RIOS, A. C.; MOUTINHO, C. G.; PINTO, F. C.; DEL FIOL, F. S.; JOZALA, A.; CHAUD, M. V.; VILA, M. M.D.C ; TEIXEIRA, J. A.; BALCÃO, V. M. Alternatives to overcoming bacterial resistances: state-of-the-art. Microbiological Research, v. 191, p. 51-80, 2016.

SHAHVERDI, A.R.; FAKHIMI, A., SHAHVERDI, H. R.; MINAIAN, S. Synthesis and effect of silver nanoparticles on the antibacterial activity of different antibiotics against Staphylococcus aureus and Escherichia coli. Nanomedicine: Nanotechnology, Biology and Medicine, v. 3, p. 168-171, 2007.

SOUZA, M. E. Antimicrobial and antibiofilm activity of Melaleuca alternifolia oil nanoparticles. 2014. 76 p. Dissertation (Master in Nanoscience) - Nanoscience Graduate Program, Centro Universitário Franciscano, Santa Maria, 2014

SUN, Y.; LI, X., CAO, J., ZHANG W., WANG, H.P. Characterization of zero-valent iron nanoparticles. Advances in Colloid and Interface Science, v. 120, p. 47-56, 2006. 